\title{
KEEFEKTIVAN PEMBELAJARAN SECARA ONLINE TERHADAP PERKEMBANGAN FISIK MOTORIK ANAK
}

\author{
Sri Wahyuni \\ IAIN Ponorogo \\ Email : Wahyusri2244@gmail.com
}

\begin{abstract}
The problem in this research is that in the online learning process the teacher cannot monitor the physical development of the child's motor skills, because children study at home and at home, the children cannot freely leave the house to play or go recreation. As a result, many parents think that playing cellphones is the main solution. The purpose of this study was to determine the effectiveness of online learning on motoric physical development. The benefits of this research are expected to provide insight, both theoretically and practically, for researchers in accordance with the focus of the research being carried out. This research is a descriptive study, while the research information is a source of reference as well as previous research. Data collection was carried out by means of observation, interview and documentation techniques. The instrument used by the researcher was a physical motor indicator. Data analysts use an interactive analysis model by collecting data, reducing data, presenting data, and drawing conclusions. The results of research on children's physical motor development during online learning have decreased.
\end{abstract}

\section{Keywords: Effectiveness, Online Learning, Physical Motor Development.}

\begin{abstract}
Abstrak: Masalah dalam ulasan ini adalah bahwa dalam proses pembelajaran internet, instruktur tidak dapat menyaring peningkatan aktual mesin anak, karena anak-anak berkonsentrasi pada tambahan di rumah dan di rumah, anak-anak tidak bisa lepas dari rumah untuk bermain. atau pergi untuk pengalihan. Oleh karena itu, banyak wali percaya bahwa bermain HP adalah pengaturan utama. Motivasi di balik tinjauan ini adalah untuk memutuskan kecukupan pembelajaran internet pada kemajuan fisik motorik anak-anak. Manfaat pemeriksaan ini diandalkan untuk memberikan pengetahuan, baik secara hipotetis maupun pada dasarnya bagi para ilmuwan sesuai dengan titik fokus eksplorasi yang telah diselesaikan. Tinjauan ini menggunakan metodologi ekspresif kuantitatif dengan strategi berbagai informasi yang memanfaatkan survei dan dari sumber referensi dan penelitian sebelumnya. Jenis tinjauan yang digunakan adalah survei tertutup, terutama subjek penelitian hanya diizinkan untuk memilih jawaban yang diperlukan untuk setiap pertanyaan. Informasi dikumpulkan dengan menggunakan survei dan strategi persepsi, pertemuan, dan dokumentasi. Alat yang digunakan oleh spesialis adalah penunjuk mesin yang sebenarnya. Pemeriksa informasi menggunakan model pemeriksaan intuitif dengan mengumpulkan informasi, mengurangi informasi, memperkenalkan informasi, dan mencapai penentuan. Efek samping dari penelitian pada peningkatan mesin anak-anak selama pembelajaran berbasis web telah berkurang.
\end{abstract}

Kata Kunci : Keefektifan, Perkembangan Fisik Motorik, Pembelajaran secara online.

\section{PENDAHULUAN}

Setiap orang tua pasti memiliki keinginan dan tujuan yang berbeda untuk masa depan anaknya. Dan setiap anak memiliki kemampuan yang 
Sri Wahyuni, Keefektifan Pembelajaran Secara Online Terhadap

Perkembangan Fisik Motorik Anak

istimewa dibalik sikap dan perilaku yang sangat menggemaskan setiap harinya. Ada masanya ketika anak harus memilih apa yang mereka citacitakan, apa yang mereka harapkan walaupun hanya sekedar pelukan dari sang ibu tercinta. Masa anak-anak adalah salah satu peristiwa utama periode penting dalam kehidupan manusia. Hal ini dikarenakan pada masa kanak-kanak orang mulai peka atau sensitif untuk mendapatkan berbagai macam dorongan dari luar dirinya. Oleh karena itu, pada masa kanak-kanak sangat penting untuk memberikan pendidikan yang layak kepada anak. Sehingga para orang tua bisa melihat kemajuan dari anak mereka dan dapat mengoptimalkan aspek-aspek apa saja yang dapat mempengaruhi perkembangan anak.

Didasarkan pada Peraturan Menteri Pendidikan dan Kebudayaan Republik Indonesia (Permendikbud) No 137 tahun 2014 tentang standar nasional pendidikan anak usia dini pada bab 1 ketentuan umum pasal 1 dan alinea kedua menyatakan bahwa "Standar Tingkat Pencapaian Perkembangan Anak Usia Dini selanjutnya disebut STPPA adalah kriteria tentang kemampuan yang dicapai anak pada seluruh aspek perkembangan dan pertumbuhan, mencakup aspek nilai agama dan moral, fisik-motorik, kognitif, bahasa, sosial-emosional, serta seni."1 Menurut kompas.com setidaknya terdapat 4 aspek tumbuh kembang yang harus dikembangkan pada anak-anak. Bagian pengembangan dan peningkatan ini terdiri dari aspek fisik-mesin, bahasa intelektual, sosio-antusias, dan sudut kreatif. Memperluas bagian perkembangan dan kemajuan pada anak-anak harus dimungkinkan dengan cara yang berbeda. Salah satu metode untuk memasukkan anak-anak ke dalam ranah pengajaran tahap awal yaitu Pendidikan Anak Usia Dini (PAUD).

\footnotetext{
${ }^{1}$ Sahal Mahfudz, "Permendikbud_137_14_Lampiran01.Pdf," dalam https://simpuh.kemenag.go.id/regulasi/permendikbud_137_14_lampiran01.pdf, (diakses pada tanggal 2 Desember 2021, jam 15.05).
} 
Mengingat Peraturan Menteri Pendidikan dan Kebudayaan Republik Indonesia (Permendikbud) Nomor 137 tahun 2014 tentang standar nasional pendidikan anak usia dini bab 1 ketentuan umum pasal 1 dan alinea kesebelas menyatakan bahwa "Satuan atau program PAUD adalah layanan PAUD yang dilaksanakan pada suatu lembaga pendidikan dalam bentuk Taman Kanak-kanak (TK)/Raudatul Athfal (RA)/Bustanul Athfal (BA), Kelompok Bermain (KB), Taman Penitipan Anak (TPA), dan Satuan PAUD Sejenis (SPS)." ${ }^{2}$

Di antara beberapa yayasan PAUD, Taman Kanak-Kanak atau biasa disebut (TK) merupakan salah satu paguyuban PAUD yang memiliki kewajiban yang lebih mencolok untuk meningkatkan prestasi pembinaan generasi muda. Hal ini dikarenakan taman kanak-kanak (TK) merupakan jenjang terakhir sebelum anak memasuki sekolah dasar. Pencapaian kemajuan yang lebih ideal ketika anak-anak keluar dari taman kanak-kanak (TK) mereka akan memiliki aksesibilitas sekolah yang lebih baik dan lebih dewasa. Persiapan sekolah yang dimiliki anak muda akan membuat anak lebih siap mengikuti pelajaran yang di sekolah. Mempunyai minat belajar tingkat inspirasi belajar yang lebih pasti dan signifikan, dan bisa mencapai prestasi akademik yang lebih baik dan memuaskan ketika masuk Sekolah Dasar. $^{3}$

Sistem pembelajaran di Taman Kanak-Kanak pada umumnya dilakukan secara dekat dan personal di wali kelas. Hal ini karena dalam pembelajaran remaja sebenarnya memerlukan arahan langsung dari pengajar, mengingat pendidik merupakan pionir hanya sebagai kepala sistem pembelajaran di wali kelas. Selain itu, dengan memimpin pembelajaran langsung di ruang belajar, instruktur dapat lebih efektif membimbing anak-anak secara langsung terkait dengan berbagai latihan

\footnotetext{
2 Ibid,.

${ }^{3}$ Ita, "Manajemen Pembelajaran Pendidikan Anak Usia Dini Di Tk Rutosoro Kecamatan Golewa Kabupaten Ngada Flores Nusa Tenggara Timur," Jurnal Dimensi Pendidikan dan Pembelajaran, Vol 2 No 1 (2018), 82-89.
} 
Sri Wahyuni, Keefektifan Pembelajaran Secara Online Terhadap

Perkembangan Fisik Motorik Anak

pembelajaran yang sedang dilakukan, sehingga memudahkan anak-anak untuk memahami pedoman pendidik, yang dengan demikian membuat sudut pembentukan lebih jelas. anak-anak membina semua lebih ideal.

Terlepas dari kenyamanan dalam pelaksanaan sistem pembelajaran yang diselesaikan langsung di ruang diagnostik, kebetulan memiliki keuntungan positif bagi perubahan waktu anak-anak, salah satunya adalah perspektif logis. Hal ini dikarenakan anak muda yang cepat berubah sesuai dengan ruang diagnosis memiliki kebebasan yang lebih besar untuk memilih berbagai jenis olahraga yang kemudian pada saat itu akan mampu memacu prestasi. prestasi yang lebih luas serta kognitif pada anak-anak. ${ }^{4}$ Demikian juga, anak-anak yang mengambil bagian dalam pembelajaran yang terlibat di sekolah juga secara bawaan lebih baik dalam kolaborasi sosial, dan lebih berpengalaman. Hal ini dikarenakan ketika anak-anak belajar di sekolah, anak-anak akan secara rutin berhubungan langsung dengan guru dan terlebih lagi dengan teman-temannya, sehingga akan mengaktifkan penyesuaian latihan sosial mereka. Oleh karena itu, dalam menyelesaikan siklus pengajaran dan pembelajaran atau dari dekat dan pribadi secara langsung di sekolah.

Para guru yang biasanya melakukan sistem pembelajaran dengan cara yang kurang maksimal. Saat ini harus melaksanakannya sebaik mungkin, mengingat sistem pembelajaran dapat diselesaikan dengan baik untuk masa depan dan sekaligus dapat meningkatkan bagian dari kemajuan pada anak-anak. Pengajaran dan latihan pembelajaran yang dilakukan secara dekat dan personal di sekolah secara tegas mempengaruhi bahasa intelektual dan sudut sosio-emosional. Lamanya percakapan dan durasi. Diskusi diselesaikan secara langsung di kalangan pendidik dan anak-anak selama sekolah bersama-sama dapat memperluas

\footnotetext{
${ }^{4}$ Miskawati Miskawati, "Upaya Meningkatkan Kreativitas Anak Dalam Pembelajaran Seni Tari Melalui Strategi Belajar Sambil Bermain Di TK Islam Sa'adatul Khidmah Tahun Pelajaran 2016/2017," Jurnal Ilmiah Dikdaya 9, no. 1 (22 April 2019),1-23.
} 
dominasi kosakata bahasa dan memberdayakan kemajuan cara pandang berpikir pada anak. Selain itu, ketika belajar secara langsung di sekolah, anak-anak dapat lebih leluasa bermain dengan teman-temannya. Kegiatan bermain yang dilakukan anak-anak ketika berada di sekolah juga terbukti menjadi salah satu faktor yang dapat mengoptimalkan perkembangan literasi anak-anak.

Namun beberapa bulan terakhir ini, akibat penyebaran wabah Covid19 diseluruh dunia termasuk Indonesia, terjadi perubahan sistem pembelajaran, sehingga membuat proses pembelajaran di taman kanakkanak tidak lagi dilakukan secara langsung melainkan secara online atau biasa disebut dengan sekolah daring. Secara formal, otoritas publik Republik Indonesia melalui Menteri Pendidikan dan Kebudayaan Republik Indonesia memberikan Surat Edaran Nomor 4 Tahun 2020 tentang Pelaksanaan Strategi Pelatihan di Masa Krisis Corona Virus Disease (Covid-19) yang menetapkan bahwa sejak 24 Maret 2020 sistem pembelajaran telah secara resmi diselesaikan di semua tingkat pengajaran, termasuk sekolah. Pemuda melakukan proses take in dari rumah melalui sistem belajar secara online. ${ }^{5}$

Mencermati pilihan kerja sama Kementerian Pendidikan dan Kebudayaan, Agama, Kesehatan, dan Dalam Negeri Republik Indonesia pada 17 Juni 2020 terkait aturan pelaksanaan tahun ajaran baru selama pandemi Covid-19, maka tidak benar-benar yakin bahwa kerangka pembelajaran berbasis web atau web di organisasi PAUD akan terus diterapkan sampai batas waktu yang belum ditentukan. ${ }^{6}$ Untuk lembaga pendidikan anak-anak yang berada di daerah atau daerah berzona hijau

\footnotetext{
${ }^{5}$ Ari Irawan, "Pusdiklat kemendikbud," dalam https://pusdiklat.kemdikbud.go.id/suratedaran-mendikbud-no-4-tahun-2020-tentang-pelaksanaan-kebijakan-pendidikan-dalammasa-darurat-penyebaran-corona-virus-disease-covid-1-9/, (diakses pada tanggal 28 desember 2021, jam 21.40).

${ }^{6}$ Siska amelia, "Kementerian Pendidikan dan Kebudayaan » Republik Indonesia," dalam https://www.kemdikbud.go.id/main/blog/2020/06/panduan-penyelenggaraanpembelajaran-pada-tahun-ajaran-dan-tahun-akademik-baru-di-masa-covid19, (diakses pada tanggal 2 desember 2021, jam 20.26).
} 
Sri Wahyuni, Keefektifan Pembelajaran Secara Online Terhadap

Perkembangan Fisik Motorik Anak

sekarang memiliki ketersediaan yang lengkap dan telah mematuhi protokol kesehatan yang mana persyaratan sudah lengkap dan sudah diterima atau di acc oleh menteri pendidikan dan kesehatan.

Maka sudah bisa melaksanakan belajar mengajar secara dari dekat dan pribadi paling cepat pada November 2020. Eksekusi ini dilakukan sesekali, dimulai dengan dengan waktu percobaan sekitar kurang lebih dua bulan. Dengan asumsi hasil menunjukkan aman itu dapat diteruskan dengan kecenderungan baru yaitu mengecek suhu tubuh ketika masuk lingkungan sekolah, cuci tangan, menjaga jarak, dan memakai masker sebanyak dua lapis atau menggunakan masker yang sudah kain yang setelah dipakai wajib untuk dibersihkan lagi. Dan sudah bisa paling lambat mulai Januari 2021. Ini salah satu pengaturan yang dilakukan otoritas publik Republik Indonesia untuk mencegah meluasnya penyebaran Covid-19.

Ketetapan Strategi pembelajaran dengan kerangka baru ini, lebih tepatnya di web atau biasa disebut dengan web, tentu saja menyebabkan perubahan kerangka belajar dan pembelajaran di taman kanak-kanak, dimana pengaruh kerangka kerja terhadap prestasi formatif anak belum diketahui. Oleh sebab itu, ulasan tersebut diarahkan pada tujuan dengan harapan bisa mengetahui prestasi formatif anak di TK selama pelaksanaan belajar berbasis web selama pandemi Covid-19.

\section{METODE PENELITIAN}

Dalam sebuah penelitian pasti harus memiliki metode dalam setiap penelitiannya. Penelitian kali ini menggunakan metodologi grafik kuantitatif dengan prosedur pengumpulan informasi dengan kerangka polling. Jenis atau macam survey yang digunakan adalah polling tertutup dimana subjek penelitian hanya diperbolehkan memilih jawaban-jawaban yang telah diakomodasi setiap pertanyaan. Pertanyaan-pertanyaan yang dikumpulkan dalam survey tersebut memuat pokok-pokok capaian formatif yang terdiri dari enak bagian peningkatan sesuai dengan pengaturan dalam 
(Permendikbud) No.137 tahun 2014 khususnya bagian moral yang ketat, fisik-motorik, kognitif-bahasa, bahasa intelektual, sosial-emosional, dan kualitas kreatif. Karena, pada penelitian kali ini penulis hanya ingin fokus pada fisik motorik anak, jadi untuk aspek perkembangannya ada tiga yaitu Motorik Kasar, Motorik Halus, dan Kesehatan.

Subyek dari penelitian ini ialah 46 pendidik TK di Sedah Jenangan, Ponorogo. Pendidik dipilih sebagai subjek dari penelitian karena pada dasarnya para peneliti sebelumnya tidak dapat menyebutkan fakta atau persepsi yang dapat diamati secara langsung dari anak-anak untuk menemukan bagaimana mereka berkreasi dan mengeksplorasi tentang diri mereka. Hal ini dikarenakan selama pandemi Covid-19, anak-anak tidak melakukan adaptasi langsung di sekolah namun melalui media secara online dari rumah masing-masing untuk menghindari perluasan penyebaran Covid-19. Pelaksanaan tatap muka ini akan dimulai pada tanggal 21 Juni 2020 dengan menyebarkan survei melalui Google Form dan kuesioner tersebut dikirimkan kepada para pengajar TK di Sedah Jenangan Ponorogo melalui grup WhatsApp para pendidik.

Tindakan yang dilakukan sebelum menyebarkan survei, adalah dengan meminta persetujuan dari atasan dan memberikan keterangan tentang diadakannya penelitian motivasi di balik tinjauan tersebut. Selain itu, para ahli juga telah menjelaskan bahwasanya dalam menjawab pertanyaan, instruktur diminta untuk secara umum melihat catatan tentang penilaian dari pencapaian bagian-bagian perkembangan anak selama pembelajaran secara pribadi di sekolah dan pencapaian bagian-bagian kemajuan anak selama belajar secara online dari rumah. Hal ini dilakukan untuk mengetahui apakah selama pembelajaran berbasis web pencapaian peningkatan anak secara keseluruhan telah berkurang atau tidak. Informasi yang didapat dari polling tersebut kemudian ditelaah menggunakan Microsoft Excel. Perkembangan eksplorasi ini dapat dilihat pada grafik di bawah ini: 


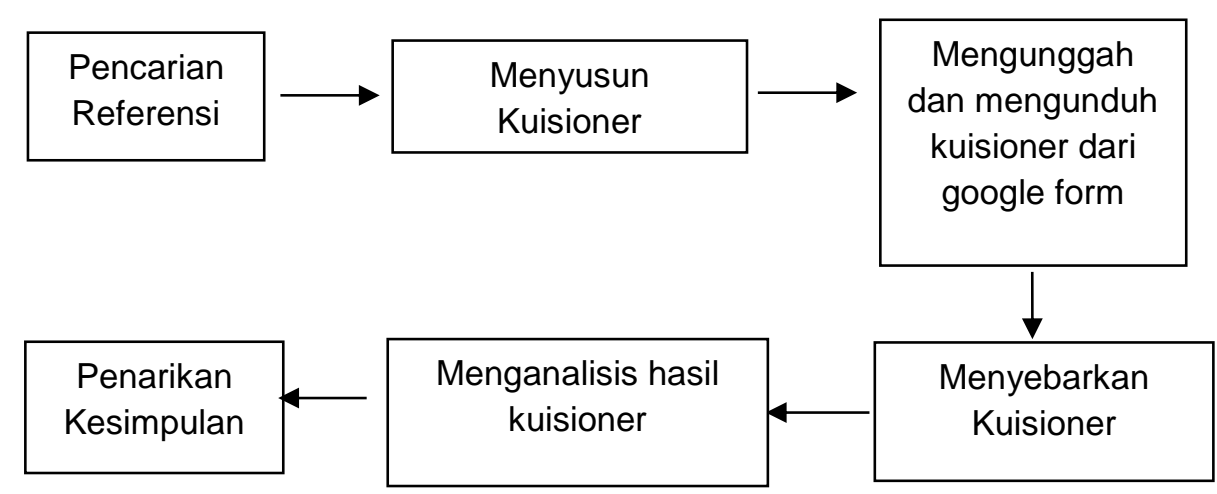

Bagan 1. Alur penelitian

\section{KERANGKA TEORI}

\section{a. Pengertian Belajar dan Pembelajaran}

Menurut kamus besar bahasa indonesia, pengertian belajar yaitu berusaha memperoleh kepandaian atau ilmu. ${ }^{7}$ Seseorang dikatakan belajar jika dalam diri orang tersebut terjadi suatu proses kegiatan yang mengakibatkan suatu perubahan tingkah laku. Beberapa pengertian belajar Menurut Robert M. Gagne Belajar adalah perubahan yang terjadi dalam kemampuan manusia yang terjadi setelah belajar terus menerus, bukan hanya disebabkan proses pertumbuhan saja. Menurut Cronbach " Learning is how by change in behavior as result of experience" yang artinya belajar adalah suatu aktivitas yang ditunjukkan oleh perubahan tingkah laku sebagai hasil dari pengalaman. Menurut Harold Spears, "Learning is to observe, to read, to imitate, to try something themselves, to listen, to follow direction" yang artinya belajar adalah mengamati, membaca, meniru, mencoba sendiri tentang sesuatu, mendengarkan, mengikuti petunjuk. Menurut asli Psikolog, belajar adalah serangkaian kegiatan jiwa raga untuk memperoleh suatu perubahan tingkah laku sebagai hasil dari pengalaman individu dalam interaksi dengan lingkungannya yang menyangkut kognitif, afektif dan psikomotorik.

\footnotetext{
7 “Hasil Pencarian - KBBI Daring," dalam https://kbbi.kemdikbud.go.id/entri/belajar, (diakses pada tanggal 6 desember 2021, jam 16.17).
} 
Pembelajaran merupakan suatu proses yang terdiri dari kombinasi dua aspek yaitu, belajar tertuju kepada apa yang harus dilakukan oleh siswa, mengajar berorientasi pada apa yang harus dilakukan oleh siswa, mengajar berorientasi pada apa yang harus dilakukan oleh guru sebagai pemberi pelajaran adalah suatu kegiatan belajar mengajar yang didalamnya terdapat interaksi positif antara guru dengan siswa dengan menggunakan segala potensi dan sumber yang ada untuk menciptakan kondisi belajar yang aktif dan menyenangkan. Usman (2012) berpendapat bahwa, ${ }^{8}$ "pembelajaran adalah inti dari proses pendidikan secara keseluruhan dengan guru sebagai pemegang peranan utama. Pembelajaran merupakan suatu proses yang mengandung serangkain guru dan siswa atas dasar hubungan timbal balik yang berlangsung dalam situasi edukatif untuk mencapai tujuan tertentu."

\section{b. Pengertian Pembelajaran Daring}

Daring adalah akronim dalam jaringan, menurut KBBI Kemendikbud pusat, yang artinya terhubung melalui jejaring komputer, internet dan sebagainya. ${ }^{9}$ Jadi kegiatan mengajar guru, dosen, siswa dan mahasiswa kini dilakukan secara belajar daring, termasuk pada saat pemberian tugas. Daring merupakan singkatan dari "Dalam Jaringan" sebagai pengganti kata online yang sering kita gunakan dalam kaitannya dengan teknologi internet. Daring adalah terjemahan dari istilah online yang bermakna tersambung ke dalam jaringan internet. ${ }^{10}$

\footnotetext{
${ }^{8}$ Ratna Galih, "PERKEMBANGAN MOTORIK AUD - Google Books," dalam https://www.google.co.id/books/edition/PERKEMBANGAN_MOTORIK_AUD/V90WEAA AQBAJ?hl=id\&gbpv=1\&dq=perkembangan+fisik\&printsec=frontcover, (diakses pada tanggal 6 desember 2021, jam 17.20).

9 "Hasil Pencarian - KBBI Daring."

10 "Buku Ajar Metode Perkembangan Fisik Anak Usia Dini - Google Books," 11, dalam https://www.google.co.id/books/edition/Buku_Ajar_Metode_Perkembangan_Fisik_Anak/l UP2DwAAQBAJ?hl=id\&gbpv=1\&dq=perkembangan+fisik\&printsec=frontcover, (diakses pada tanggal 6 desember 2021, jam 17.24).
} 
Sri Wahyuni, Keefektifan Pembelajaran Secara Online Terhadap

Perkembangan Fisik Motorik Anak

Pembelajaran daring artinya adalah pembelajaran yang dilakukan secara online, menggunakan aplikasi pembelajaran maupun jejaring sosial. Belajar online merupakan strategi pembelajaran yang memanfaatkan model cerdas berbasis web dan learning the board framework (LMS). Seperti memanfaatkan Zoom, Google Meet, dan lainnya. Belajar pada hakikatnya ialah suatu proses interaksi terhadap situasi yang ada disekitar individu. Dalam aktivitas kehidupan manusia sehari-hari hampir tidak pernah dapat terlepas dari latihan belajar, baik ketika individu melakukan latihan sendiri, memang sebagian besar latihan dalam kehidupan seharihari.

\section{c. Perkembangan anak usia dini}

Tumbuh dan kembang adalah kata dasarnya, sedangkan pertumbuhan dan perkembangan telah menjadi nomina, kedua istilah ini umumnya digunakan dalam dunia psikologi. Berbicara tentang perkembangan, tentu tidak terlepas dari fisik seseorang, di mana telah kita ketahui fisik manusia mengalami perkembangan dari sejak dilahirkan hingga dewasa. Sebagaimana seorang bayi yang baru dilahirkan, tidak berdaya dan hanya bisa menangis, kemudian beberapa bulan bayi tersebut mulai berkembang, bisa lebih banyak gerak seperti: mirinr, tengkurap, berguling kemudia belajar duduk dan merangkak lalu bayi tersebut berubah menjadi anak kecil. Namun perkembangan tersebut dilalui sesuai dengan usia pertumbuhannya.

Perkembangan motorik adalah perkembangan di mana seseorang sudah mulai mampu mengontrol gerakan yang diperoleh dari pengalaman yang ia rasakan. Menurut Rini Hildayani menyatakan bahwa "Perbaikan motorik (engine advance) adalah perubahan dinamis yang bertanggung jawab atas kemampuan untuk melakukan suatu perkembangan yang dapat diperoleh dari hubungan antara faktor perkembangan dan 
latihan/pertemuan selama hidup yang seharusnya dilakukan. terlihat melalui perubahan yang terjadi sepanjang kehidupan sehari-hari.

Usia bisa dibedakan menjadi dua macam, yaitu usia kronologis dan usia biologis: ${ }^{11}$

1. Usia kronologis adalah usia sesuai dengan bertambahnya umur setiap tahunnya (ulang tahun). Semua anak akan merasakan usia ini, biak anka yang sehat maupun yang sepanjang tahunnya dia sakit.

2. Usia biologis adalah usia dengan bertambahnya sambungan sel pada otak anak yang ditentukan oleh berapa banyak rangsangan yang membangun yang diberikan kepada anak. Perkembangan anak yang dicapai merupakan integritas aspek pemahaman nilainilai agama dan moral.

Dan perkembangan lain dalam jurnal prinsip perkembangan sebagai berikut; $^{12}$

1. Perkembangan merupakan proses yang tidak pernah berhenti (never ending process), artinya manusia secara terus menerus berkembang dipengaruhi oleh pengalaman atau belajar.

2. Semua aspek perkembangan saling memengaruhi artinya setiap aspek perkembangan individu baik fisik, emosi, inteligensi maupun sosial saling memengaruhi jika salah satu aspek tersebut tidak ada.

3. Perkembangan itu mengikuti pola atau arah tertentu, artinya perkembangan terjadi secara teratur sehingga hasil perkembangan dari tahap sebelumnya yang merupakan prasyarat bagi perkembangan selanjutnya.

${ }^{11}$ Khadijah dan Nurul Amelia, Perkembangan Fisik Motorik Anak Usia Dini: Teori dan Praktik (Prenada Media, 2020), 32.

12 "Pembelajaran Daring untuk Pendidikan: Teori dan Penerapan - Google Books," dalam https://www.google.co.id/books/edition/Pembelajaran_Daring_untuk_Pendidikan_Teo/iu z4DwAAQBAJ?hl=id\&gbpv=1\&dq=pembelajaran+daring\&printsec=frontcover (diakses pada tanggal 6 desember 2021, jam 17.30), 58-59. 
Sri Wahyuni, Keefektifan Pembelajaran Secara Online Terhadap

Perkembangan Fisik Motorik Anak

\section{d. Ciri-ciri Perkembangan anak usia dini}

Manusia tidak pernah dalam keadaan statis. Sejak terjadi proses pembuahan sampai hayat sudah tidak dikandung badan, manusia selalu berubah dan mengalami perubahan. Perubahan tersebut bisa menanjak, kemudian berada di titik puncak kemudian mengalami kemunduran. Peningkatan ini pada umumnya memiliki kualitas yang menyertainya:

1. Terjadinya perubahan cara pandang dan cara pandang yang sebenarnya.

2. Ada penyesuaian luasnya, khususnya sudut pandang aktual dan perspektif mental.

3. Lenyapnya tanda-tanda lama, khususnya tanda-tanda aktual dan tanda-tanda mental.

4. Hilangnya tanda-tanda baru, khususnya tanda-tanda aktual dan tanda-tanda mental.

Janet black melihat bahwa tumbuh kembang anak melalui tahap-tahap sebagai berikut:

1. Tahap infancy 1 (0-1 tahun). Aspek yang sedang berkembang pada tahap ini adalah.

a. Perkembangan fisik dan motorik

b. Perkembangan psikososial

c. Perkembangan kognitif

d. Perkembangan bahasa

2. Tahap infancy II (1-3) sama dengan tahap 1 hanya saja tingkat kematangannya berbeda.

3. Tahap anak umur 4-5 tahun. Sama dengan masa infancy.

Berbeda dengan Janet black, Elizabeth B. Hurblock, berpendapat bahwa kemajuan anak dapat dilihat dari bagian periode atau usia tertentu. Bagian-bagian dari perbaikan ini adalah kemajuan motorik yang sebenarnya, antusiasme sosial, etika yang ketat dan pergantian peristiwa 
intelektual. ${ }^{13}$ Prinsip-prinsip penting dalam perkembangan motorik, sebagai berikut:
a. Kematangan
b. Urutan
C. Motivasi
d. Pengalaman
e. Praktik

Dari berbagai macam pendapat penulis dapat menarik kesimpulan bahwa perkembangan motorik berasal dari psikis dan pertumbuhan anak dari sejak dini.

\section{TEMUAN DAN PEMBAHASAN}

Kemajuan fisik dan kemajuan sistem gerak anak atau biasa disebut motorik mempunyai pengertian yang bermacam-macam. Perkembangan fisik-motorik yang terjadi pada anak berkaitan dengan peningkatan sistem sensorik, otot, organ endoktrin, dan juga struktur fisik/tubuh. Sementara kemajuan sistem motorik terkait dengan kemampuan anak untuk melakukan banyak hal atau hal yang sebenarnya. Seperti menggerakkan jari dan tangannya, berjalan, berlari, atau memainkan mata yang berputar mengikuti arah jarum jam. Meskipun kapasitas dan koordinasi sebenarnya berkembang secara langsung pada anak-anak. Namun, kemampuan nyata dan koordinasi yang baik pada anak-anak telah ditunjukkan untuk memberi anak-anak kesehatan yang lebih siap dan sehat. Sistem kekebalan pada anak-anak menjadi lebih kuat seiring bertambahnya usia pada anak-anak. Anak-anak yang memiliki kemajuan besar juga memiliki otak yang cerdas dan kegembiraan mereka yang meningkat juga menjadi luar biasa.

\footnotetext{
13 "Pembelajaran Daring Yang Efektif: Prinsip Dasar, Pengembangan, Desain, Dan ... Google Books," dalam https://www.google.co.id/books/edition/Pembelajaran_Daring_Yang_Efektif_Prinsip/UjE 7EAAAQBAJ? $\mathrm{hl}=\mathrm{id} \& \mathrm{gbpv}=1 \& \mathrm{dq}=$ pembelajaran+daring \&printsec=frontcover, , (diakses pada tanggal 6 desember 2021, jam 17.35), 45-47.
} 
Sri Wahyuni, Keefektifan Pembelajaran Secara Online Terhadap

Perkembangan Fisik Motorik Anak

Sementara itu, tujuan kemajuan motorik yang baik dimasa anak juga telah ditunjukkan untuk mempengaruhi prestasi ilmiah di kemudian hari.

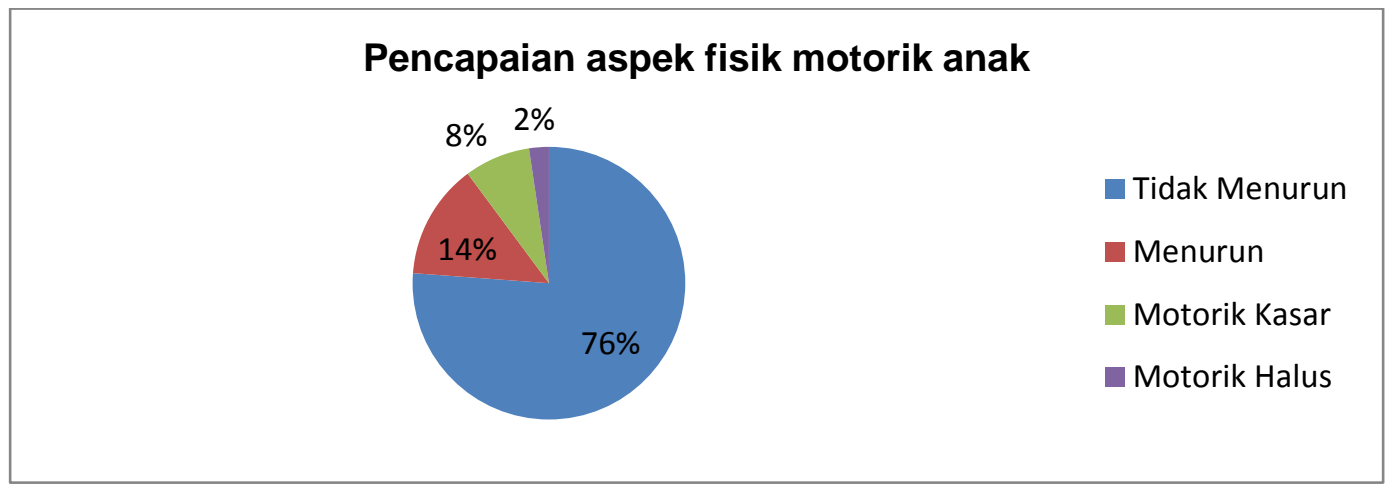

Memperoleh peningkatan fisik dan motorik yang luar biasa pada anak-anak telah terbukti memiliki efek positif, baik sekarang maupun nanti. Oleh karena itu, sangat penting untuk membidik dalam memperoleh perspektif ini sejak awal. Dari diagram di atas, sangat mungkin beralasan bahwa pamflet atau guru mengatakan bahwa penurunan prestasi kemajuan anak pada perspektif sistem motorik sebenarnya Cuma sedikit, terutama di bagian sistem motorik, baik di sistem kasar maupun halus.

Sistem ini didukung oleh bukti bahwasanya kemajuan anak bisa dengan tegas menerima iklim kritis yang ada baik di lingkungan sekolah maupun di luar lingkungan sekolah atau rumah. Selain itu, gerakan fisik dan koordinasi yang didapat anak bisa dapat kemajuan dilakukan dengan baik jika menerima dukungan oleh keadaan sekitarnya saat ini. Jadi, pada saat keadaan yang mendukung anak untuk tidak belajar maka anak itu akan mengikuti apa yang dilakukan pada lingkungannya. Kecuali, dari lingkungan keluarga sudah tegas terhadap anaknya dan membuat anak disiplin serta bertanggung jawab dengan apa yang dia kerjakan. Walaupun tidak sedikit keluarga yang tidak mendukung apa kemauan anak. Tapi 99\% keluarga terutama orang tua pasti mendukung kemauan anaknya. Baik dari lingkungan di dalam dan di luar kelas akan berlaku sikap sama saja jika tidak ada yang mengontrol mereka. Kemajuan motorik yang berkembang dengan baik pada anak, secara khusus pada sistem motorik halus 
mempunyai peran yang sangat penting pada mata pelajaran matematika dasar anak.

\section{KESIMPULAN}

Pembelajaran internet memainkan peran penting dalam mencapai peningkatan anak. Hasil dari tinjauan tersebut menganggap bahwa sebagian besar pencapaian formatif anak-anak di sudut aspek motorik mengalami penurunan kritis namun tidak langsung. Hasil review ini selanjutnya dapat dimanfaatkan sebagai sumber perspektif untuk menguji pelaksanaan pembelajaran internet di taman kanak-kanak (TK). Mengingat bahwa pembelajaran berbasis web akan berlangsung tanpa henti. Tinjauan ini memiliki kendala, pertama dan terutama, mata pelajaran eksplorasi tidak banyak dan sedikit ekstensi, sehingga hasilnya tidak dapat diperkenalkan secara umum. Kedua, tujuan review adalah untuk mengetahui pencapaian perbaikan tanpa menemukan unsur-unsur penyebab dari sudut pandang yang dimaksud pada anak. Jadi bagian percakapan hanya menggunakan ujung pemeriksaan langsung untuk menggambarkan variabel apa yang mungkin menjadi alasan untuk perspektif yang diteliti. Pemeriksaan lebih lanjut, disarankan untuk memasukkan lebih banyak mata pelajaran dan gelar yang lebih luas dan kemudian menyelidiki variabel penyebab dari sudut pandang yang diteliti.

\section{DAFTAR PUSTAKA}

"Buku Ajar Metode Perkembangan Fisik Anak Usia Dini - Google Books."dalam https://www.google.co.id/books/edition/Buku_Ajar_Metode_Perkem bangan_Fisik_Anak/IUP2DwAAQBAJ?hl=id\&gbpv=1\&dq=perkemb angan+fisik\&printsec=frontcover, (diakses pada tanggal 6 desember 2021, jam 16.17).

Fauziddin, Moh. "Meningkatkan Kemampuan Motorik Halus Melalui Teknik Mozaik Pada Anak Kelompok B Di TK Perdana Bangkinang Kota." Journal of Studies in Early Childhood Education (J-SECE) 1, no. 1 (18 Februari 2018). 1-12. 
Sri Wahyuni, Keefektifan Pembelajaran Secara Online Terhadap

Perkembangan Fisik Motorik Anak

Hamdani, Acep Roni, dan Asep Priatna. "Efektifitas Implementasi Pembelajaran Daring (Full Online) Dimasa Pandemi Covid- 19 Pada Jenjang Sekolah Dasar Di Kabupaten Subang." Didaktik: Jurnal IImiah PGSD STKIP Subang 6, no. 1 (27 Juni 2020). 1-9..

"Hasil Pencarian - $\mathrm{KBBI}$ Daring." dalam https://kbbi.kemdikbud.go.id/entri/belajar. (diakses pada tanggal 6 desember 2021, jam 16. 20).

"Kementerian Pendidikan dan Kebudayaan » Republik Indonesia." dalam https://www.kemdikbud.go.id/main/blog/2020/06/panduanpenyelenggaraan-pembelajaran-pada-tahun-ajaran-dan-tahunakademik-baru-di-masa-covid19. (diakses pada tanggal 2 desember 2021, jam 16.30).

Khadijah, dan Nurul Amelia. Perkembangan Fisik Motorik Anak Usia Dini: Teori dan Praktik. Jakarta: Prenada Media, 2020.

Ita. "Manajemen Pembelajaran Pendidikan Anak Usia Dini Di Tk Rutosoro Kecamatan Golewa Kabupaten Ngada Flores Nusa Tenggara Timur." Jurnal Dimensi Pendidikan dan Pembelajaran. Vol 2 No 1 (2018).

Miskawati, Miskawati. "Upaya Meningkatkan Kreativitas Anak Dalam Pembelajaran Seni Tari Melalui Strategi Belajar Sambil Bermain Di TK Islam Sa'adatul Khidmah Tahun Pelajaran 2016/2017." Jurnal IImiah Dikdaya 9, no. 1 (22 April 2019). 45-54..

"Pembelajaran Daring untuk Pendidikan: Teori dan Penerapan - Google Books." dalam https://www.google.co.id/books/edition/Pembelajaran_Daring_untuk Pendidikan_Teo/iuz4DwAAQBAJ?hl=id\&gbpv=1\&dq=pembelajara $\bar{n}+$ daring\&printse $=$ frontcover. (diakses pada tanggal 6 desember 2021, jam 16.35).

"Pembelajaran Daring Yang Efektif: Prinsip Dasar, Pengembangan, Desain, Dan ... - $\quad$ Google Books." dalam https://www.google.co.id/books/edition/Pembelajaran_Daring_Yang _Efektif_Prinsip/UjE7EAAAQBAJ?hl=id\&gbpv=1\&dq=pembelajaran +daring\&printsec=frontcover. (diakses pada tanggal 6 desember 2021, jam 17.00).

"PERKEMBANGAN MOTORIK AUD - Google Books." dalam https://www.google.co.id/books/edition/PERKEMBANGAN_MOTOR IK_AUD/V90WEAAAQBAJ?hl=id\&gbpv=1\&dq=perkembangan+fisik \&printsec=frontcover. (diakses pada tanggal 6 desember 2021, jam 17.12). 
WISDOM: JURNAL PENDIDIKAN ANAK USIA DINI Volume 02 No. 02 Juli - Desember 2021

"permendikbud_137_14_lampiran01.pdf." dalam https://simpuh.kemenag.go.id/regulasi/permendikbud_137_14_lam piran01.pdf. (diaskes pada tanggal 2 desember 2021, jam 15.17).

Rismayanthi, Cerika. "Mengembangkan Keterampilan Gerak Dasar Sebagai Stimulasi Motorik Bagi Anak Taman Kanak-Kanak Melalui Aktivitas Jasmani." Jurnal Pendidikan Jasmani Indonesia 9, no. 1 (1 April 2013). 89-97. 